\title{
Adsorption of Lead (II) from Aqueous Solution Using Adsorbents Obtained from Nanche Stone (Byrsonima Crassifolia)
}

Luis Armando Bernal-Jácome ${ }^{1}$, Lizeth Olvera-Izaguirre ${ }^{1}$, Marisol Gallegos García ${ }^{1}$, Raúl Delgado-Delgado ${ }^{2}$, Miguel Ángel Espinosa Rodríguez ${ }^{2 *}$

${ }^{1}$ Programa de Maestría en Tecnología y Gestión del Agua. Facultad de Ingeniería, Universidad Autónoma de San Luis Potosí. Av. Dr. Manuel Nava No. 8 Zona Universitaria, C.P. 78290, San Luis Potosí, S.L.P. México. ${ }^{2}$ Programa Académico de Ingeniería Química de la Unidad Académica de Ciencias Básicas e Ingenierías, Universidad Autónoma de Nayarit. Ciudad de la Cultura Amado Nervo S/N, C.P 63155, Tepic, Nayarit, México.

*Corresponding author: Miguel Ángel Espinosa Rodríguez, email: emiguel@uan.edu.mx

Received April 21 $1^{\text {st }}, 2020$; Accepted September 13 $3^{\text {th }}, 2020$.

DOI: http://dx.doi.org/10.29356/jmcs.v64i4.1201

\begin{abstract}
The removal capacity of $\mathrm{Pb}$ (II) present in aqueous solution was evaluated, using as a sorbent the nanche stone (Byrsonima crassifolia) naturally (NS), modified with citric acid (MNS) and as activated carbon (AC). The point of zero charge ( $\mathrm{pH}_{\mathrm{PZC}}$ ) and the active sites (using the Boehm method and FTIR spectroscopy) were determined. The $\mathrm{pH}$ PZC of NS, MNS and AC were in an acid range. The concentration of active sites of NS, MNS and AC were $0.1037,0.1123$ y $0.1404 \mathrm{~mol} / \mathrm{g}$, respectively. The infrared spectra (FTIR) detected the formation of acid functional sites associated with the phenol group, carboxylic acids and lactones. The adsorption capacity of lead ions using NS, MNS and AC increases with the increment of the $\mathrm{pH}$ of the solution from 3 to 5; nevertheless, at $\mathrm{pH} 5$, precipitation of lead ions is observed. Due to the above, the evaluation of the three materials was carried out at $\mathrm{pH} 4$. Comparing the maximum capacity of adsorption of $\mathrm{Pb}$ (II) on NS with respect to MNS and $\mathrm{AC}$ at $\mathrm{pH} 4$, it was increased in 2.2 and 10 times, respectively. The chemical modification applied to precursor, as well as its formation to AC, improved their adsorption capacity due to a greater generation of acid sites. The experimental data were represented with the models of Langmuir, Freundlich and Prausnitz-Radke and the parameter values of these isotherms were estimated using a least-squares method which utlilizes an optimization algorithm.
\end{abstract}

Keywords: Adsorption; nanche stone; $\mathrm{Pb}(\mathrm{II})$.

Resumen. Se evaluó la capacidad de remoción de $\mathrm{Pb}(\mathrm{II})$ presente en solución acuosa, utilizando como adsorbente el hueso de nanche (Byrsonima crassifolia) de forma natural (HN), modificado con ácido cítrico (HNM) y como carbón activado CA. Se determinaron el punto de carga cero (pHPZC) y los sitios activos (utilizando el método Boehm y espectroscopía FTIR). El pHPZC del HN, HNM y CA estuvo en un rango ácido. La concentración de sitios ácidos del HN, HNM y CA fueron de $0.1037,0.1123$ y $0.1404 \mathrm{~mol} / \mathrm{g}$ respectivamente. Los espectros infrarrojos (FTIR), detectaron la formación de sitios funcionales ácidos asociados al grupo fenol, ácidos carboxílicos y lactonas. La capacidad de adsorción del ion plomo con el HN, HNM y CA, aumentó al incrementarse el pH de la solución de 3 a 5; sin embargo, a pH 5, se observó precipitación de iones plomo. Debido a lo anterior, la evaluación de los tres materiales se realizó a pH 4. Comparando la máxima capacidad de adsorción de $\mathrm{Pb}(\mathrm{II})$ en el $\mathrm{HN}$ con respecto al HNM y al CA a pH 4, se incrementó en 2.2 y 10 veces, respectivamente. La modificación química aplicada al precursor, así como su formación a CA, amplió su poder de adsorción al desarrollarse una mayor cantidad de sitios activos ácidos. Los datos experimentales se representaron con los modelos de Langmuir, Freundlich y Prausnitz-Radke, y los 
valores de los parámetros de estas isotermas fueron estimados usando un método de mínimos cuadrados que utiliza un algoritmo de optimización.

Palabras clave: Adsorción; hueso de nanche; $\mathrm{Pb}(\mathrm{II})$.

\section{Introduction}

In recent years, agricultural wastes have been used in adsorption processes for lead ion $(\mathrm{Pb}(\mathrm{II}))$ removal from aqueous solution. Several sources as cocoa pod, banana stem, rice husk, coconut husk, papaya and melon rind, soya waste, grape seeds, nut shells, moringa and cane bagasse have been used to remove $\mathrm{Pb}^{2+}[1-3]$.

An agricultural waste has a certain capacity for adsorption but if it is chemically modified, his adsorption capacity is increased through cation exchange. Citric acid has been used as oxidant agent to modify the surface chemistry of a precursor $[1,4]$.

Furthermore, agricultural wastes have been used to obtain activated carbon (AC). The AC has result being a highly effective adsorbent for removal of a wide variety of organic and inorganic contaminants and metal ions in aqueous media. Activated carbon has been obtained from bamboo stalk, cane bagasse, olive stone, cherry stone, oil coconut stone, peach stone, nut shell, pine cone, acorn shell, coconut shell, tobacco waste, coffee waste, industrial tea waste, pistachio and walnuts wood, etc. [5-7].

The nanche tree or changunga (Byrsonima crassifolia) can grow wild or cultivated. It is localized in tropical and subtropical regions of Mexico, specifically in the gulf states: Tamaulipas, San Luis Potosí, Veracruz, Tabasco, Yucatán and Quintana Roo, and the states of the Pacific Mexican Coast: Sinaloa, Nayarit, Michoacán, Guerrero, Oaxaca and Chiapas. There are many species of this fruit, nevertheless the morphological characterization is very similar regarding the fruit (mesocarp), stone (endocarp) and seed $[8,9]$. The nanche stone waste are generated by agroindustry and several satisfiers (food, medicinal, ornamental, fuel, tanning, coloring, beekeeping, fodder and timber) [10-12].

Activated carbon continues to be widely used for the removal of toxic compounds present in wastewater, so the search for low-cost precursors is convenient to streamline municipal and industrial water treatment processes, and if these materials come from agricultural waste, also helps to solve the problem of elimination of these [13].

A few years ago, several researchs have been carried out in order to improve the adsorptive properties of natural materials due to their low cost for removing heavy metals, being the main agent used, citric acid $[13,14]$.

Recently, experimental designs have been proposed to improve the uptake properties of Byrsonima crassifolia biomass using a chemical modification with citric acid for the removal of heavy metals under competitive sorption conditions [14].

The aim of this work is to use the nanche stone in three different ways: 1) Nanche stone without treatment (NS), 2) modified nanche stone with citric acid (MNS) and 3) activated carbon obtained from the nanche stone (AC), to remove $\mathrm{Pb}(\mathrm{II})$ ions from aqueous solutions. The adsorption capacity of the three different treatments performed to precursor was analyzed in terms of the $\mathrm{pH}$ and lead concentration.

\section{Experimental}

\section{Materials and Methods}

\section{Preparation of nanche stone}

The nanche stone was washed with a $0.01 \mathrm{M}$ hydrochloric acid $(\mathrm{HCl})$ solution to remove the pulp (mesocarp) from the sample. Subsequently, removal of $\mathrm{HCl}$ from nanche stone was carried out using distillated water. The nanche stone was dried at $60{ }^{\circ} \mathrm{C}$ and the dry material was ground until to reach a particle size of 14 
mesh. The ground nanche stone was used as raw material to obtain the following three adsorbents: nanche stone without treatment (NS), modified nanche stone (MNS) and activated carbon (AC).

\section{Oxidation of nanche stone}

The superficial chemistry of the ground nanche stone (NS) was modified using a $1 \mathrm{M}$ citric acid $\left(\mathrm{C}_{6} \mathrm{H}_{8} \mathrm{O}_{7}\right)$ solution. A $50 \mathrm{~mL}$ solution of citric acid was added to each $10 \mathrm{~g}$ of ground nanche stone. The solution with the nanche stone grounded was heated at $55^{\circ} \mathrm{C}$ during $2 \mathrm{~h}$ then cooled to reach the room temperature and drained. Subsequently, the nanche stone was dried in a stove at $50{ }^{\circ} \mathrm{C}$ for $24 \mathrm{~h}$ and at $120^{\circ} \mathrm{C}$ for $3 \mathrm{~h}$. The cold nanche stone was washed with distilled water to reach the neutral $\mathrm{pH}$. Finally, the nanche stone was again dried at $50{ }^{\circ} \mathrm{C}$ during $24 \mathrm{~h}$ to be characterized and used in the experimental tests as MNS.

\section{Carbonization and activation of nanche stone}

The ground nanche stone (NS) was carbonized and activated in a tube furnace (Carbolite model MTF). The activation of the carbon was carried out chemically, using zinc chloride $\left(\mathrm{ZnCl}_{2}\right)$ as activating agent. The temperature and the optimal carbonization time were determined through a thermogravimetric analysis, obtaining values of $450^{\circ} \mathrm{C}$ and $25 \mathrm{~min}$, respectively. The impregnated material with activating agent was placed in the quartz tube of the furnace. The carbonization temperature, activation time, heat rate and nitrogen flow values were entered to the programmable control system of the furnace. Once the optimum temperature was reached, it remained constant for the determined time $(25 \mathrm{~min})$. AC was obtained with relationships: $\mathrm{AC}: \mathrm{ZnCl}_{2}$ $1.0: 0.5 ; 1.0: 1.0$ and $1.0: 1.5$.

\section{Determination of the $\mathrm{pH} P \mathrm{PzC}$}

The adsorbent material was mixed with deionized water free of $\mathrm{CO}_{2}$. Carbon dioxide was completely removed from the deionized water by boiling during $20 \mathrm{~min}$. A mixture of $1.0 \mathrm{~g}$ of adsorbent with $20 \mathrm{~mL}$ of deionized water was heated at $25{ }^{\circ} \mathrm{C}$ with constant agitation for $48 \mathrm{~h}$. Finally, the $\mathrm{pH}$ of the solution was measured, corresponding to the pHpzc.

\section{Superficial chemistry (active sites)}

The quantity of active sites of NS, MNS and AC was determined using the acid-base titration method proposed by Boehm [15]. A solution containing $0.3 \mathrm{~g}$ of adsorbent material, $20 \mathrm{~mL}$ of $1 \mathrm{M} \mathrm{HCl}$ solution and 20 $\mathrm{mL}$ of $1 \mathrm{M}$ sodium hydroxide solution $(\mathrm{NaOH})$ was prepared separately. The solutions were stirred during 120 $\mathrm{h}$ at $25{ }^{\circ} \mathrm{C}$ until an equilibrium was reached. At the end of the stirring time, each of the samples was filtered and the entire filtered volume was taken for neutralization. The total acid sites and total basic sites were neutralized with $1 \mathrm{M} \mathrm{NaOH}$ solution and $1 \mathrm{M} \mathrm{HCl}$ solution, respectively.

\section{FTIR Characterization}

Infrared spectra for the three adsorbents (NS, MNS and AC) were obtained using a Fourier transform infrared spectrometer (FTIR) (Thermo Scientific model Nicolete iS10 Smart iTR). The samples were analyzed in the mid-infrared region (4000-400 $\left.\mathrm{cm}^{-1}\right)$ using the method of attenuated total reflectance.

\section{Equilibrium adsorption isotherms}

A lead standard solution with an initial concentration of $1,000 \mathrm{mg} / \mathrm{L}$ was prepared. The solution was prepared with lead nitrate $\left[\mathrm{Pb}\left(\mathrm{NO}_{3}\right)_{2}\right]$, purity $99 \%$, Merck brand graduated in $1 \mathrm{~L}$ of deionized water. Dilutions at different concentrations $(10,30,50,100 \mathrm{mg} / \mathrm{L}$ etc.) were made from this solution. $50 \mathrm{~mL}$ of the solutions with different concentrations of $\mathrm{Pb}^{2+}$ were added in $100 \mathrm{~mL}$ bottles. Subsequently, $1.0 \mathrm{~g}$ of adsorbent was added to each solution and $\mathrm{pH}$ was adjusted to 3,4 and 5 . The solutions were maintained at $25{ }^{\circ} \mathrm{C}$ with sporadic agitation for 7 days until an equilibrium was reached. The $\mathrm{pH}$ of all the mixtures was adjusted daily with $\mathrm{NaOH}$ and $\mathrm{HNO}_{3} 0.1 \mathrm{~N}$ as appropriate. Afterwards, mixtures were filtered to remove the adsorbent and $\mathrm{Pb}^{2+}$ concentration was determined by an ICP-OES spectrometer Thermo Scientific Model iCAP 7000. 
The equilibrium data were analyzed in accordance with the Langmuir adsorption isotherm as:

$q_{e}=\frac{q_{\max } b C e}{1+b C e}$

where, $\mathrm{q}_{\mathrm{e}}$ is the metal ion uptake ( $\mathrm{mg} / \mathrm{g}$ adsorbent), $\mathrm{q}_{\max }$ is the maximum sorption capacity corresponding to complete monolayer coverage $(\mathrm{mg} / \mathrm{g}), \mathrm{C}_{\mathrm{e}}$ is the equilibrium solute concentration $(\mathrm{mg} / \mathrm{L})$ and " $b$ " is a constant relative to the energy of sorption $(\mathrm{L} / \mathrm{mg})$.

The Freundlich model:

$q_{e}=k C e^{1 / n}$

being " $k$ " Freundlich constant that is related to the adsorption capacity and " $1 / \mathrm{n}$ " is related to the adsorption intensity of the adsorbent.

And the Prausnitz-Radke model is represented by the following equation:

$$
q_{e}=\frac{a C e}{1+b C e^{\beta}}
$$

where, $a, b$ y $\beta$ are constants of the Prausnitz-Radke isotherm.

The values of the isotherm constants were estimated using a least-squares method based on an optimization algorithm.

The adsorption capacity of the studied materials in the removal process of $\mathrm{Pb}(\mathrm{II})$ was calculated according to the mass balance (Equation 4):

$$
q_{\infty}=\frac{V\left(C_{A o}-C_{A \infty}\right)}{m}
$$

where, $q_{\infty}$ (metal solute uptake, $\mathrm{mg} / \mathrm{g}$ adsorbent), $V$ (solution volume, L), $C_{A o}$ (initial solute concentration, $\mathrm{mg} / \mathrm{L}$ ), $C_{A \infty}$ (equilibrium solute concentration, $\mathrm{mg} / \mathrm{L}$ ) y $m$ (mass of the adsorbent, g).

\section{Results and discussion}

\section{Chemical characterization}

The chemical characterization for nanche stone without treatment (NS), modified nanche stone (MNS) and activated carbon (AC) is presented in Table 1. 
Table 1. Chemical characterization for of the adsorbent materials.

\begin{tabular}{|c|c|c|c|}
\hline Material & Acid sites (mol/g) & Basic sites (mol/g) & pHPZC \\
\hline NS & 0.1037 & 0.046 & 6.0 \\
\hline MNS & 0.1123 & 0.042 & 5.6 \\
\hline AC & 0.1404 & 0.044 & 5.9 \\
\hline
\end{tabular}

According with Table 1, formation of acid sites was favored when NS is oxidized by citric acid, increasing significantly their concentration. This can be attributed to the fact that the surface of the adsorbent was modified, thereby increasing the presence of oxygenated groups [16]. The chemical modification has been used to increase the adsorption capacity of cations in contact with agricultural wastes [1].

In the case of carbon activation with $\mathrm{ZnCl}_{2}$, the concentration of acid sites was further increased. The aqueous solutions of $\mathrm{ZnCl}_{2}$ present an acid character due to the $\mathrm{Zn}^{2+}$ ions act as a Lewis acid, thus the $\mathrm{ZnCl}_{2}$ acts as a dehydration agent during the carbonization process, resulting in charring and aromatization reactions and development of the pore structure. Also, molecular hydrogen is evolved from the hydroaromatic structure of the precursor and leaves behind some sites for reaction [17-19].

With reference to $\mathrm{pH}_{\mathrm{PZC}}$, the results of the NS, MNS and AC are maintained in acidic zones, which is consistent with the result of the concentration of acid sites, presenting a significant decrease in the zero charge point when the NS is oxidized with citric acid. The pHpzc values obtained for MNS and AC indicate the acidic nature of the adsorbent materials due to the treatment applied, which caused the insertion of oxygenated groups. The pHpzc value is the point at which the superficial functional groups do not contribute to the $\mathrm{pH}$ of the solution [1].

On the other hand, the speciation diagram of the lead obtained with the $\mathrm{Pb}\left(\mathrm{NO}_{3}\right)_{2}$ salt, showed the $\mathrm{pH}$ range with which we worked (Fig. 1). A predominance of $\mathrm{Pb}^{2+}$ at $\mathrm{pH} 5.5$ can be observed in Fig. 1, while at $\mathrm{pH}$ 5.0 the precipitate formation of lead hydroxide $\left[\mathrm{Pb}(\mathrm{OH})_{2(\mathrm{~s})}\right]$ and the soluble specie $\left[\mathrm{Pb}(\mathrm{OH})^{+}\right]$starts occurring. Also, at $\mathrm{pH}$ between 12 and 13, the most common species of hydroxide are $\mathrm{Pb}(\mathrm{OH})_{4}{ }^{2-}$ y $\mathrm{Pb}(\mathrm{OH})^{3-}$. Based on the speciation diagram, it was decided to analyze the removal of $\mathrm{Pb}^{2+}$ at $\mathrm{pH} 3,4$ and 5 .

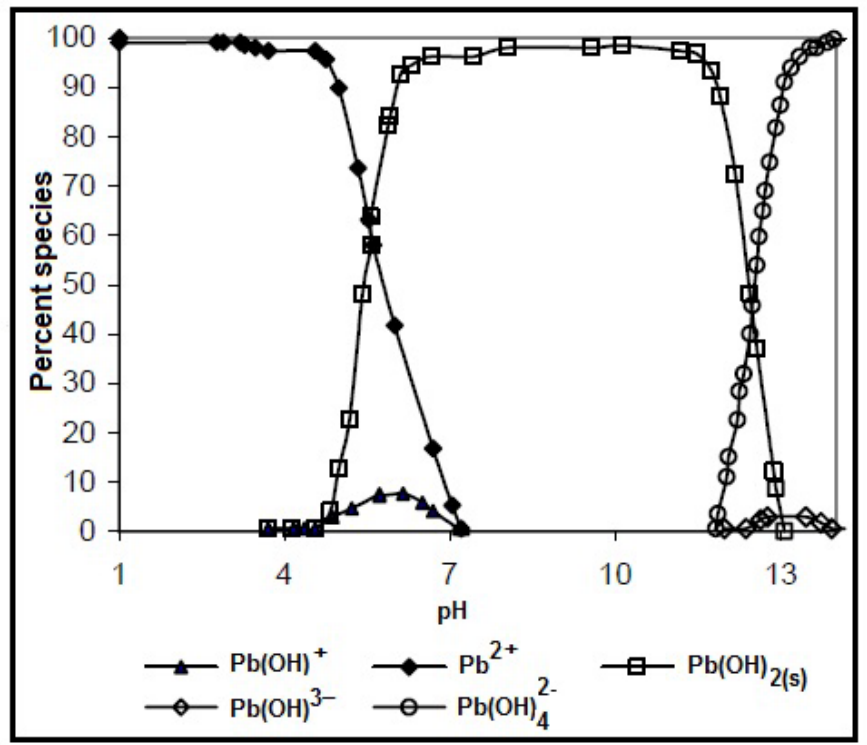

Fig. 1. Lead species as a function of $\mathrm{pH}$. [20]

According to Fig. 1, the ions $\mathrm{Pb}^{2+}$ predominates at $\mathrm{pH}<5.5$, which indicates a $\mathrm{pH}<\mathrm{pH}$ PZC (Table 1). It is assumed, then, that $\mathrm{H}^{+}$ions are released from the surface of the solid, while being negatively charged; this, 
in turn, favors the adsorption of the lead ion. At $\mathrm{pH}>\mathrm{pH}_{\mathrm{PZC}}$ the functional groups of the adsorbent surface are protonated. Also known that the point of zero charge (pHpzc), which is indicative of the types of active centers on the surface and the adsorption mobility of the surface, is an important factor in adsorption processes [21, 22].

On the other hand, at $\mathrm{pH}>\mathrm{pHpzc}$, the hydroxylated species affect the adsorption process, particularly the $\mathrm{Pb}(\mathrm{OH})_{2(\mathrm{ss})}$ that starts to precipitate on the adsorbent surface, and consequently the adsorption of lead ions decreases. These results are in correspondence with those reported by other authors [1, 20, 23, 24].

\section{FTIR Characterization}

Fig. 2 shows the infrared spectra obtained for NS, MNS and AC. Peaks are observed that are characteristic of acidic functional groups which sequester heavy metals. Three important bands can be noticed: 1) the band between 3200 and $3600 \mathrm{~cm}-1$ which is associated to phenol group $(\mathrm{O}-\mathrm{H}), 2)$ the band from 2800 to $3100 \mathrm{~cm}-1$ related to carboxylic acid groups (R-COOH), and 3) the band between 1600 and $1800 \mathrm{~cm}-1$ related to vibrations of lactone groups $(\mathrm{C}=\mathrm{O})[21,22,25]$. According to Fig. 2 , the intensity of peaks defined above was higher for AC in comparison with those for NS and MNS. This suggests an increment in the quantity of phenolic and carboxylic groups.

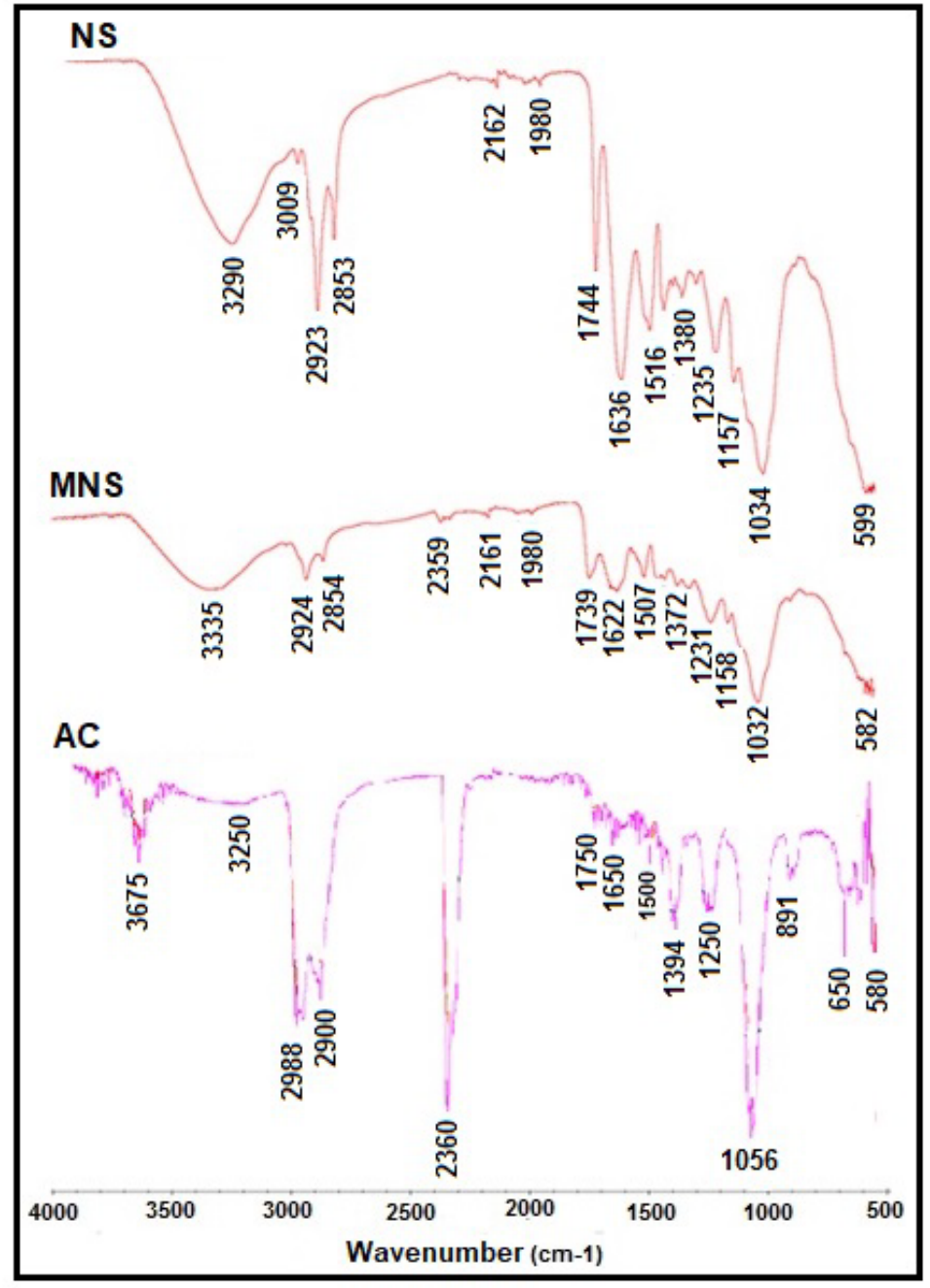

Fig. 2. Infrared spectra of NS, MNS and AC. 


\section{Equilibrium Adsorption Isotherms}

Table 2 shows the results obtained from the absorbed mass of $\mathrm{Pb}^{2+}$ for each gram of NS, represented trough the Langmuir, Freundlich and Prausnitz-Radke models.

Table 2. Results of the mathematical models at $\mathrm{pH} 3,4$, and 5 for NS.

\begin{tabular}{|c|c|c|c|c|c|c|c|c|}
\hline pH & Ce (mg/L) & $\begin{array}{c}\text { qexp } \\
(\mathbf{m g} / \mathbf{g})\end{array}$ & $\begin{array}{c}\text { qLangmuir } \\
(\mathbf{m g} / \mathbf{g})\end{array}$ & \% Desv & $\begin{array}{c}\text { qFreundlich } \\
(\mathbf{m g} / \mathbf{g})\end{array}$ & \% Desv & $\begin{array}{c}\text { qPrausnitz } \\
(\mathbf{m g} / \mathbf{g})\end{array}$ & \% Desv \\
\hline \multirow{4}{*}{3} & 8.80 & 1.19 & 1.00 & 18.73 & 0.75 & 57.17 & 1.16 & 1.98 \\
\cline { 2 - 9 } & 18.90 & 1.64 & 1.91 & 14.24 & 1.62 & 0.75 & 1.85 & 11.64 \\
\cline { 2 - 9 } & 21.80 & 2.25 & 2.13 & 5.68 & 1.87 & 20.27 & 2.05 & 10.13 \\
\cline { 2 - 9 } & 43.80 & 3.48 & 3.46 & 0.60 & 3.76 & 7.47 & 3.49 & 0.42 \\
\hline \multirow{4}{*}{4} & 11.10 & 0.79 & 1.73 & 54.46 & 1.47 & 46.09 & 0.79 & 0.11 \\
\cline { 2 - 9 } & 15.90 & 2.15 & 2.28 & 5.47 & 2.11 & 1.90 & 2.13 & 0.71 \\
\cline { 2 - 9 } & 26.50 & 3.46 & 3.23 & 7.11 & 3.51 & 1.33 & 3.61 & 4.10 \\
\cline { 2 - 9 } & 33.90 & 4.73 & 3.74 & 26.57 & 4.49 & 5.33 & 4.63 & 2.36 \\
\hline \multirow{4}{*}{5} & 2.40 & 1.23 & 1.97 & 37.53 & 1.95 & 37.14 & 1.93 & 36.09 \\
\cline { 2 - 9 } & 4.80 & 4.17 & 3.62 & 15.29 & 3.49 & 19.63 & 3.44 & 21.23 \\
\cline { 2 - 9 } & 9.70 & 6.44 & 6.35 & 1.44 & 6.31 & 2.12 & 6.31 & 2.11 \\
\cline { 2 - 8 } & 11.45 & 7.00 & 7.15 & 2.20 & 7.25 & 3.44 & 7.28 & 3.87 \\
\hline
\end{tabular}

According to Table 2, the percentage of standard deviation for the Langmuir and Prausnitz-Radke models indicated the best fits to the experimental data for all $\mathrm{pH}$ studied. However, the adjustment of the Freundlich model was comparable to the Langmuir and Prausnitz-Radke models at pH 5. Fig. 3, 4 and 5 show the experimental and predicted dependence of the mass of absorbed lead (q) on equilibrium concentration $(\mathrm{Ce})$ for $\mathrm{pH} \mathrm{3,4}$ and 5 using the models described above (Table 2).

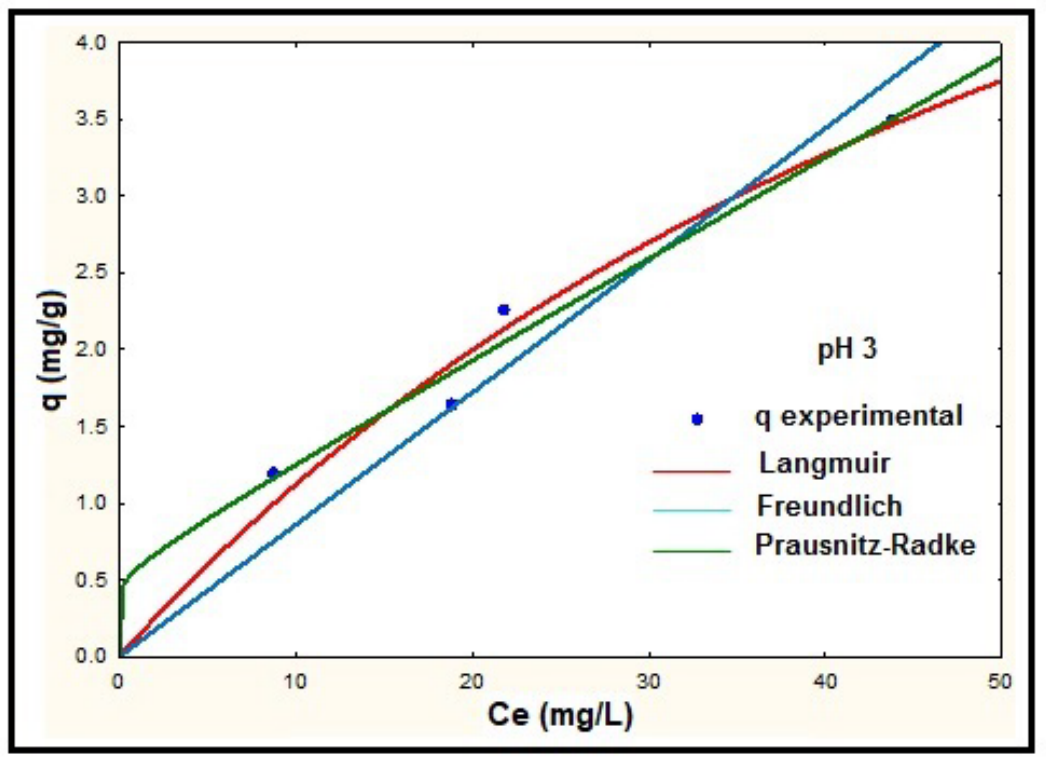

Fig. 3. Adsorption isotherms of $\mathrm{NS}$ at $\mathrm{pH} 3$. 


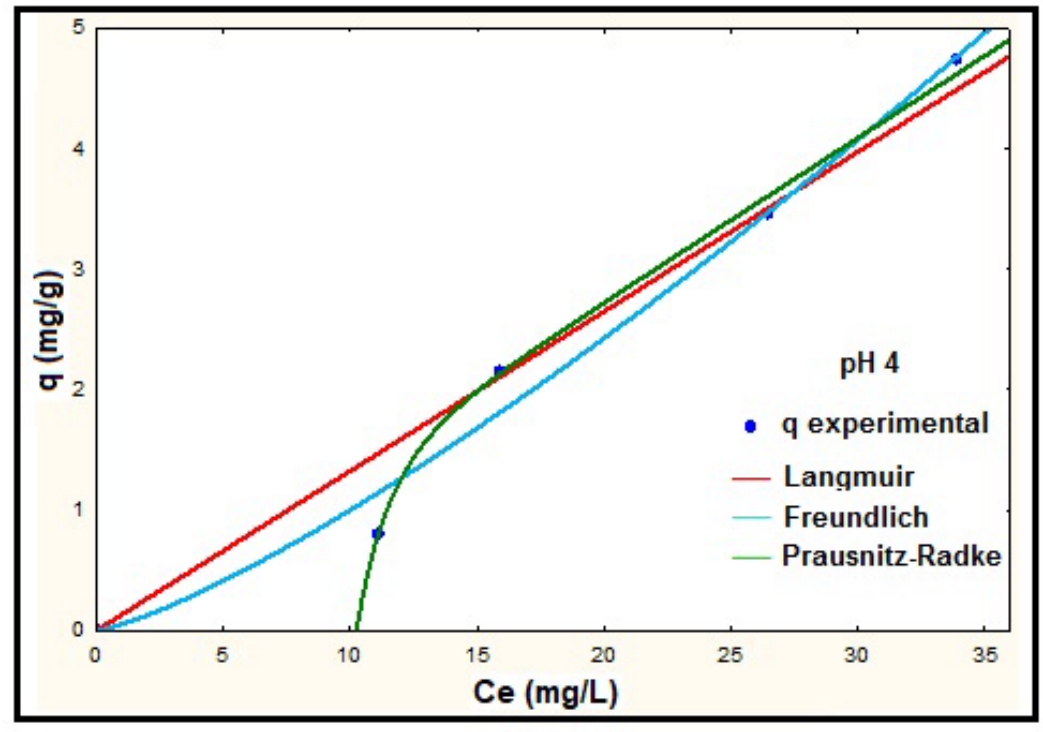

Fig. 4. Adsorption isotherms of NS at pH 4.

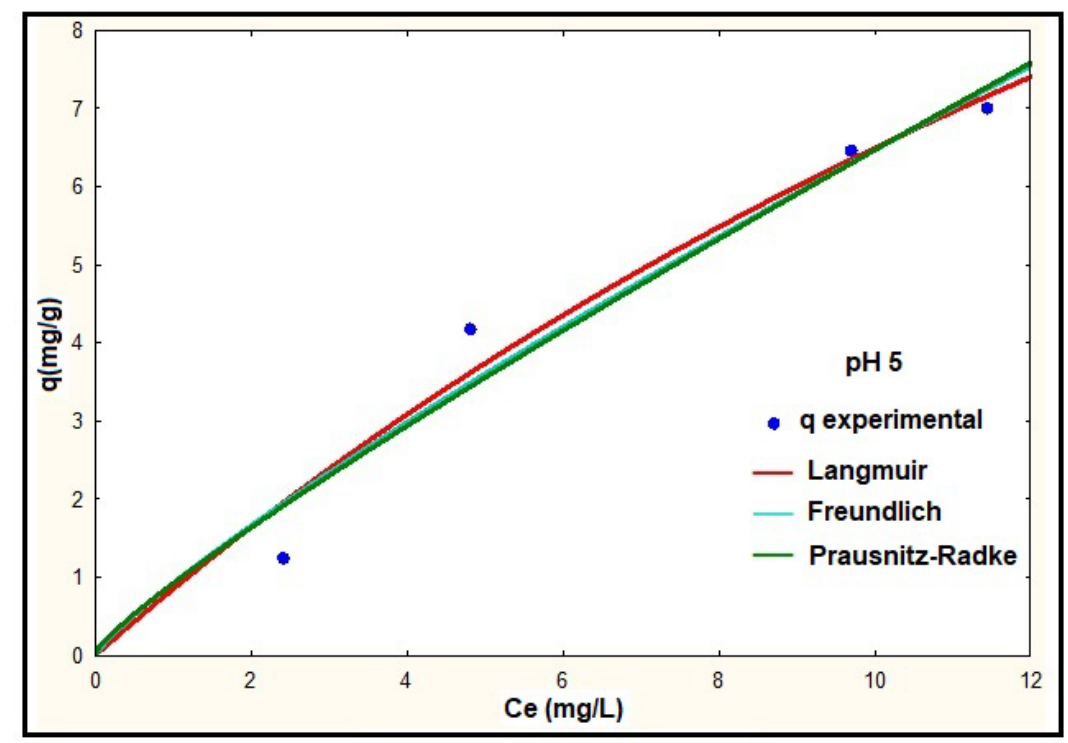

Fig. 5. Adsorption isotherms of NS at pH 5.

According to the results showed in Fig. 3, 4 and 5 it is observed that at higher $\mathrm{pH}$ the adsorbed mass of lead increases, presenting the best removal efficiencies at $\mathrm{pH}$ 5. The best fit to the experimental data was presented by the Langmuir model at all $\mathrm{pH}$ studied. On the other hand, the isotherm for the Prausnitz-Radke model was not fit properly at $\mathrm{pH}$ 4. Thus, a representation of isotherms of equilibrium using the Langmuir model was carried out and it is showed in Fig. 6. 


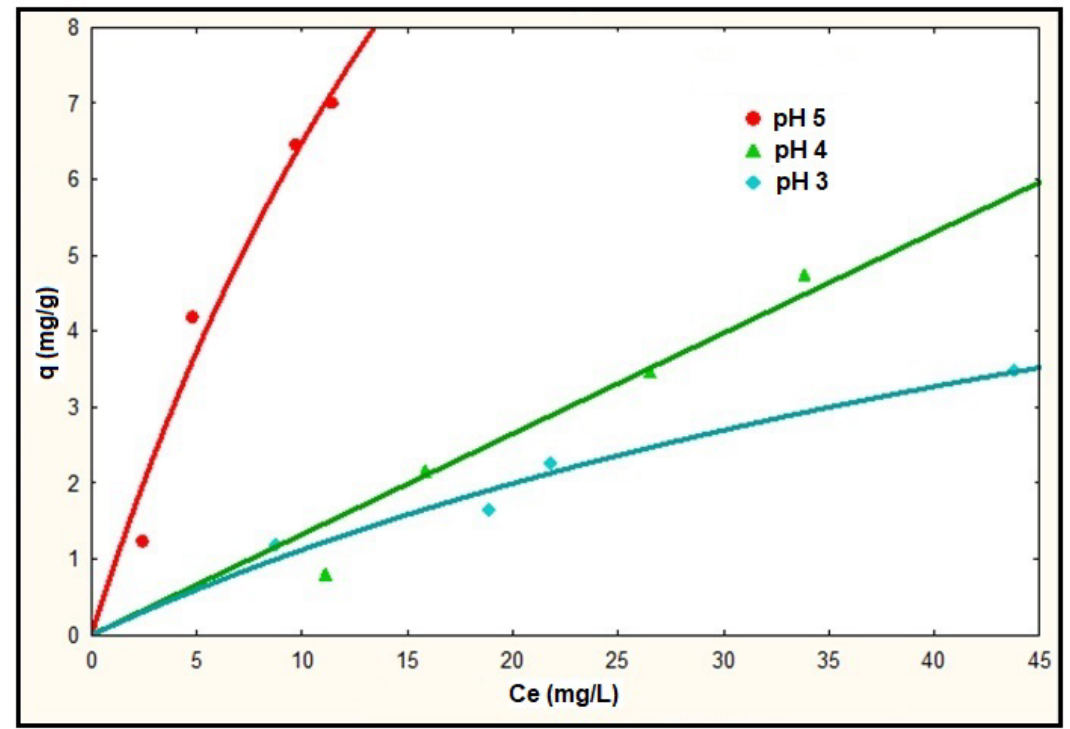

Fig. 6. Adsorption isotherms of NS using the Langmuir model.

The greatest adsorption capacity of lead in aqueous solution was obtained at $\mathrm{pH} 5$, as can be observed in Fig. 6, however according to the speciation diagram (Fig. 1), the $\mathrm{Pb}^{2+}$ ion begins to precipitate at $\mathrm{pH} 5$; this was observed during the adsorption tests, so it was decided to carry out the investigation at $\mathrm{pH} 4$. Therefore, the experimental tests using the MNS was carried out at $\mathrm{pH}$ 4. These results were compared with those obtained using NS and they are shown in Fig. 7.

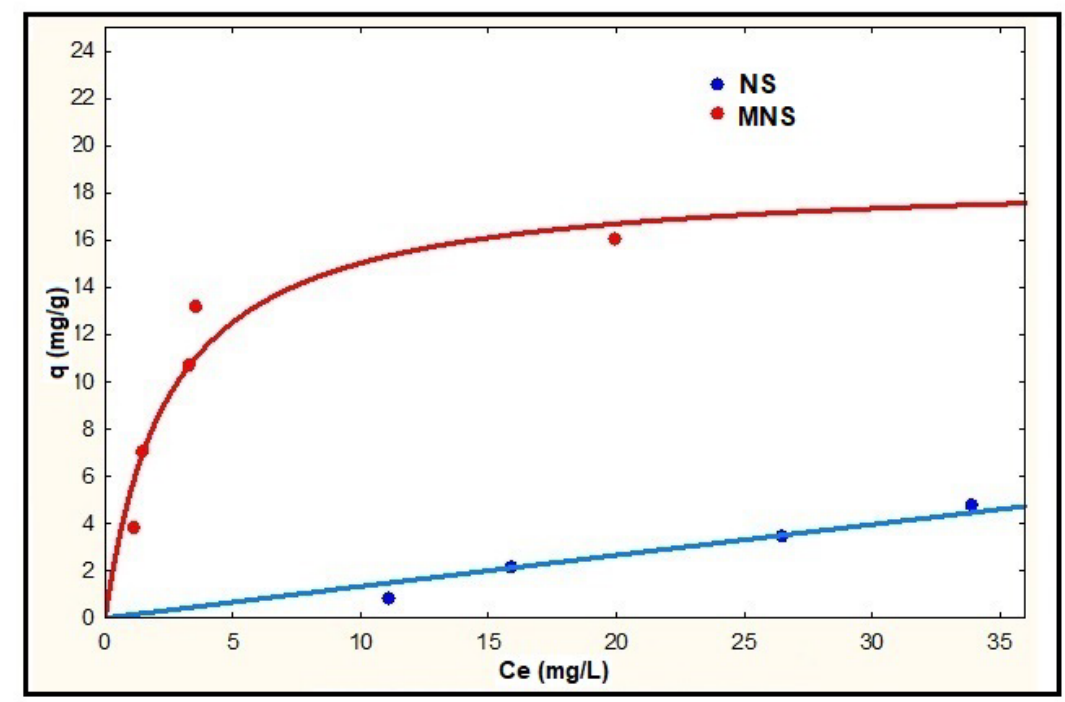

Fig. 7. Langmuir models for NS and MNS at pH 4.

The results represented in Fig. 7 show that MNS has a higher adsorption capacity than NS; the oxidation of NS with citric acid decreased the pHpzc (Table 1) and therefore modified the surface chemistry of the adsorbent obtaining a greater number of acidic active sites that impacted the adsorption capacity of the lead ion [16]. 
Finally, equilibria parameters for the AC were obtained using different ratios of adsorbent material and activating agent $\left(\mathrm{AC}: \mathrm{ZnCl}_{2}\right)$. These results, shown in Table 3, were taken as a base in the determination of the amount of $\mathrm{AC}$ used for the lead adsorption tests at $\mathrm{pH} 4$.

Table 3. Results of mathematical models at $\mathrm{pH} 4$ for AC.

\begin{tabular}{|c|c|c|c|c|c|c|c|c|}
\hline $\mathrm{AC}: \mathrm{ZnCl}_{2}$ & $\mathrm{Ce}(\mathrm{mg} / \mathrm{L})$ & $\begin{array}{c}q_{\exp } \\
(\mathrm{mg} / \mathrm{g})\end{array}$ & $\begin{array}{c}\text { qLangmuir } \\
\text { (mg/g) }\end{array}$ & \% Desv & $\begin{array}{c}\text { QFreundlich } \\
\text { (mg/g) }\end{array}$ & \% Desv & $\begin{array}{l}\text { qPrausnitz } \\
\text { (mg/g) }\end{array}$ & \% Desv \\
\hline \multirow{5}{*}{ 1.0:0.5 } & 1.10 & 20.13 & 13.98 & 43.94 & 23.03 & 12.58 & 17.54 & 14.73 \\
\hline & 5.55 & 35.66 & 43.54 & 18.10 & 41.58 & 14.23 & 40.19 & 11.27 \\
\hline & 6.10 & 52.25 & 45.85 & 13.96 & 43.13 & 21.13 & 41.94 & 24.58 \\
\hline & 18.30 & 64.09 & 68.68 & 6.69 & 64.31 & 0.34 & 63.59 & 0.78 \\
\hline & 36.60 & 82.16 & 78.61 & 4.52 & 82.96 & 0.96 & 80.27 & 2.36 \\
\hline \multirow{5}{*}{ 1.0:1.0 } & 1.30 & 23.33 & 26.56 & 12.17 & 33.14 & 29.59 & 26.57 & 12.20 \\
\hline & 1.80 & 36.11 & 32.14 & 12.10 & 35.96 & 0.42 & 32.20 & 12.16 \\
\hline & 5.90 & 48.14 & 56.77 & 15.21 & 50.44 & 4.56 & 57.11 & 15.72 \\
\hline & 6.60 & 66.94 & 58.95 & 13.00 & 52.16 & 28.34 & 59.30 & 12.89 \\
\hline & 32.00 & 77.25 & 77.54 & 0.30 & 81.37 & 5.07 & 77.44 & 0.25 \\
\hline \multirow{5}{*}{$1.0: 1.5$} & 0.80 & 18.56 & 21.36 & 13.10 & 26.50 & 29.95 & 11.67 & 59.04 \\
\hline & 1.55 & 36.06 & 32.24 & 11.84 & 31.75 & 13.56 & 15.66 & 130.21 \\
\hline & 6.00 & 50.76 & 53.20 & 4.58 & 45.71 & 11.06 & 26.14 & 94.22 \\
\hline & 20.00 & 64.23 & 63.28 & 1.51 & 63.41 & 1.30 & 32.90 & 95.25 \\
\hline & 25.60 & 64.45 & 64.35 & 0.15 & 67.55 & 4.60 & 32.29 & 99.58 \\
\hline
\end{tabular}

The results of Table 3 show that the best fit to the experimental data based on the percentage of standard deviation was for the Freundlich model using an $\mathrm{AC}: \mathrm{ZnCl}_{2}$ ratio of 1.0:0.5, while for $\mathrm{AC}: \mathrm{ZnCl}_{2}$ ratios of 1.0:1.0 and 1.0:1.5 was for the Langmuir model. However, according to the adsorption capacity at equilibrium, the lowest lead removal efficiency occurred with the $1.0: 1.5$ ratio, while with the ratio $1.0: 0.5$ and $1.0: 1.0$ they were similar, which is also observed in Fig. 8. Considering the above two $\mathrm{AC}: \mathrm{ZnCl}_{2}$ ratios, the best adjustment was obtained using the Langmuir model at an $\mathrm{AC}: \mathrm{ZnCl}_{2}$ ratio of 1.0:1.0. In this context, Fig. 8 shows the $\mathrm{Pb}^{2+}$ adsorption isotherms at $\mathrm{pH} 4$ with the Langmuir model for the different $\mathrm{AC}-\mathrm{ZnCl}_{2}$ ratios.

Considering the results shown in Table 3 and Fig. 8, in Table 4, the results of the adsorption equilibrium at pH 4 are presented with the Langmuir model for NS, MNS and AC (1:1), same as are represented in Fig. 9.

The results represented by the Langmuir isotherms of Fig. 9, show an increase in the adsorption capacity with the AC produced from the nanche stone (NS). Making a comparison of the adsorbed mass of $\mathrm{Pb}^{2+}$ per gram of adsorbent using the values of $\mathrm{q}_{\max }$ shown in Table 4, the adsorption capacity increases 2.2 and 10 times compared with MNS and with AC (1:1), respectively.

This significant increase in the adsorption of the $\mathrm{Pb}^{2+}$ ion with AC with respect to NS and MNS, is due to the fact that there was a greater formation of acid sites, as detailed in chemical characterization and FTIR, but the generation of interspaces in the $\mathrm{AC}$ is also assumed due to the formation of pores and greater superficial area. The increase of the porosity could be attributed to the expansion (swelling) of molecular structure of cellulose contained in the carbon by the action of activation with $\mathrm{ZnCl}_{2}$ [19,26]. Agricultural residues contain high levels of lignocellulosic material (cellulose, hemicellulose and lignin), which is the raw material for the synthesis of activated carbon [25,27]. Other studies have found that the activation of carbon with $\mathrm{ZnCl}_{2}$ increase its superficial area and pore volume favoring the adsorption process [19,27-29].

In Table 5 presented results referent to the maximum adsorption capacity $\left(\mathrm{q}_{\max }\right)$ of the $\mathrm{Pb}^{2+}$ ion in aqueous solution with agricultural wastes, modified agricultural wastes and AC elaborated from lignocellulosic material. 


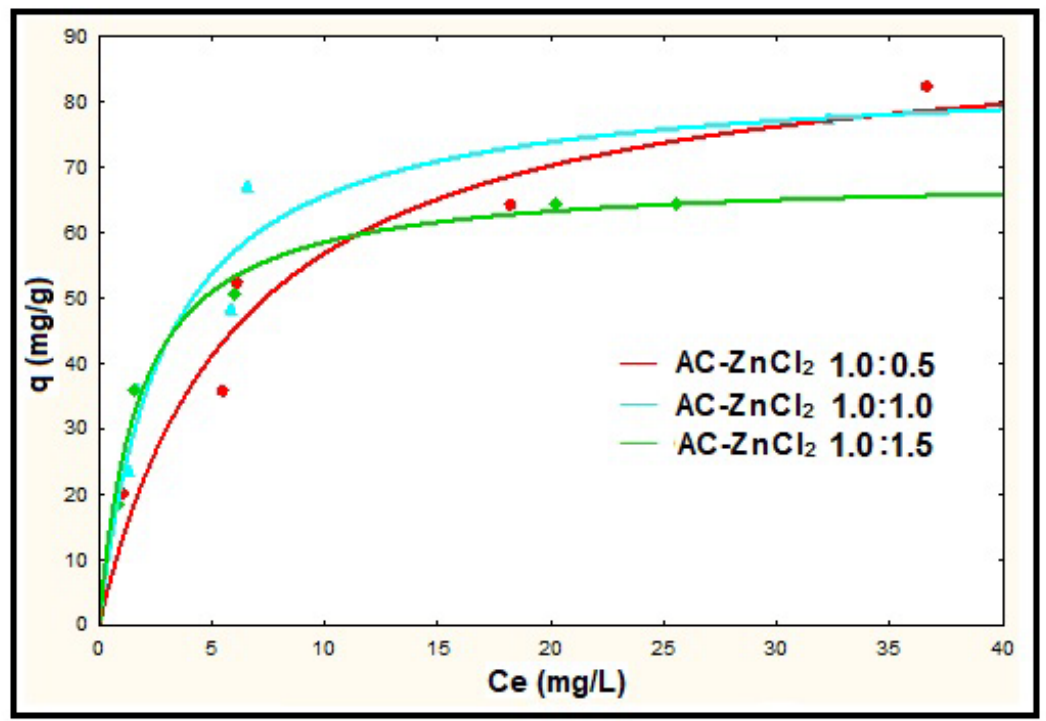

Fig. 8. Langmuir models for $\mathrm{AC}: \mathrm{ZnCl}_{2}$ ratios at $\mathrm{pH} 4$.

Table 4. Langmuir model results and parameters at $\mathrm{pH} 4$ for NS, MNS and AC.

\begin{tabular}{|c|c|c|c|c|c|c|c|}
\hline \multirow[t]{2}{*}{ Adsorbent } & \multirow[t]{2}{*}{ pH } & \multirow[t]{2}{*}{$\mathrm{Ce}(\mathrm{mg} / \mathrm{L})$} & \multirow[t]{2}{*}{$\begin{array}{c}\text { qexp } \\
(\mathrm{mg} / \mathrm{g})\end{array}$} & \multirow[t]{2}{*}{$\begin{array}{l}\text { qLangmuir } \\
\text { (mg/g) }\end{array}$} & \multirow[t]{2}{*}{ \% Desv } & \multicolumn{2}{|c|}{$\begin{array}{c}\text { Parameters of the } \\
\text { model }\end{array}$} \\
\hline & & & & & & $q_{\max }$ & b \\
\hline \multirow{4}{*}{ NS } & \multirow{4}{*}{4} & 11.1 & 0.79 & 1.73 & 54.46 & \multirow{4}{*}{8.53} & \multirow{4}{*}{0.023} \\
\hline & & 15.9 & 2.15 & 2.28 & 5.47 & & \\
\hline & & 26.5 & 3.46 & 3.23 & 7.11 & & \\
\hline & & 33.9 & 4.73 & 3.74 & 26.57 & & \\
\hline \multirow{5}{*}{ MNS } & \multirow{5}{*}{4} & 1.16 & 3.81 & 5.94 & 35.76 & \multirow{5}{*}{18.78} & \multirow{5}{*}{0.40} \\
\hline & & 1.45 & 7.02 & 6.91 & 1.59 & & \\
\hline & & 3.33 & 10.66 & 10.73 & 0.60 & & \\
\hline & & 3.57 & 13.17 & 11.05 & 19.20 & & \\
\hline & & 19.95 & 16.03 & 16.69 & 3.92 & & \\
\hline \multirow{5}{*}{$\mathrm{AC}(1: 1)$} & \multirow{5}{*}{4} & 1.31 & 23.33 & 26.56 & 12.17 & \multirow{5}{*}{84.38} & \multirow{5}{*}{0.35} \\
\hline & & 1.76 & 36.11 & 32.14 & 12.37 & & \\
\hline & & 5.88 & 48.14 & 56.77 & 15.21 & & \\
\hline & & 6.62 & 66.94 & 58.95 & 13.56 & & \\
\hline & & 32.40 & 77.25 & 77.54 & 0.38 & & \\
\hline
\end{tabular}




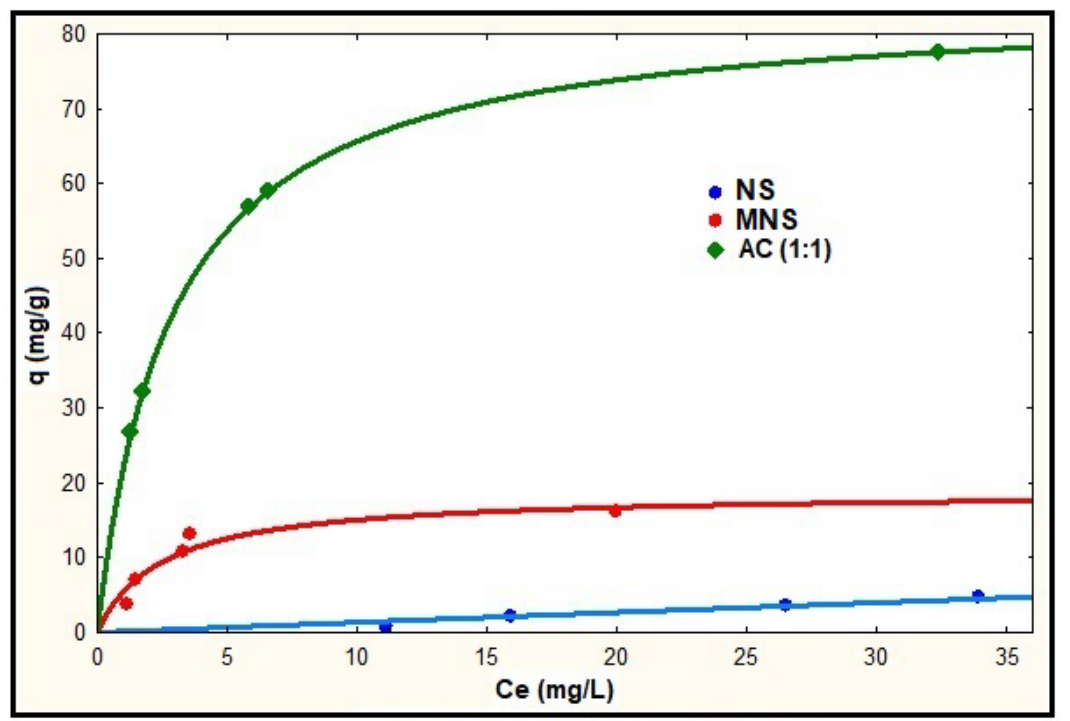

Fig. 9. Langmuir models for $\mathrm{NS}, \mathrm{MNS}$ and $\mathrm{AC}: \mathrm{ZnCl}_{2}(1: 1)$ at $\mathrm{pH} 4$

Table 5. Comparison of the maximum adsorption capacity $\left(\mathrm{q}_{\max }\right)$ of $\mathrm{Pb}^{2+}$ with different adsorbents

\begin{tabular}{|c|c|c|}
\hline Adsorbent & $q_{\max } \mathbf{m g} / \mathbf{g}$ & References \\
\hline \multicolumn{3}{|l|}{ Agricultural wastes } \\
\hline Almond shell & 2.00 & [30] \\
\hline Cashew nut shell & 1.38 & [31] \\
\hline Walnut shell & 9.91 & [32] \\
\hline Peach stone & 0.0023 & [33] \\
\hline Apricot stone & 0.0013 & [33] \\
\hline Olive stone & 3.455 & [34] \\
\hline Hazelnut shell & 16.23 & [35] \\
\hline Almond shell & 5.43 & [35] \\
\hline \multicolumn{3}{|c|}{$\begin{array}{c}\text { Modified agricultural wastes } \\
\end{array}$} \\
\hline Modified cashew nut shell with $\mathrm{H}_{2} \mathrm{SO}_{4}$ & 8.73 & [25] \\
\hline Modified walnut shell with $\mathrm{HCl}$ & 2.97 & [36] \\
\hline Modified walnut shell with $\mathrm{NaOH}$ & 7.79 & [36] \\
\hline Modified coconut shell with $\mathrm{H}_{2} \mathrm{SO}_{4}$ & 24.24 & [37] \\
\hline Modified peanut husk with $\mathrm{H}_{2} \mathrm{SO}_{4}$ & 4.66 & [38] \\
\hline \multicolumn{3}{|c|}{ AC produced from agricultural wastes } \\
\hline AC developed from peanut shell & 59.00 & [22] \\
\hline $\mathrm{AC}$ developed from dinde stone & 92.90 & [22] \\
\hline $\mathrm{AC}$ with $\mathrm{H}_{3} \mathrm{PO}_{4}$ developed from olive stone & 148.77 & [39] \\
\hline AC with $\mathrm{H}_{2} \mathrm{O}_{2}$ developed from coconut shell & 65.00 & {$[40]$} \\
\hline AC with $\mathrm{H}_{2} \mathrm{SO}_{4}$ developed from jujube stone & 71.43 & [41] \\
\hline AC with $\mathrm{H}_{2} \mathrm{SO}_{4}$ developed from apricot stone & 21.38 & [42] \\
\hline AC with $\mathrm{KOH}$ developed from olive stone & 22.37 & [43] \\
\hline AC with $\mathrm{H}_{3} \mathrm{PO}_{4}$ developed from date stone & 11.85 & [44] \\
\hline AC with $\mathrm{H}_{2} \mathrm{SO}_{4}$ developed from peach stone & 19.43 & [45] \\
\hline AC with $\mathrm{ZnCl}_{2}$ developed sea-buckthorn stone & 25.91 & [46] \\
\hline AC with $\mathrm{H}_{3} \mathrm{PO}_{4}$ developed sea-buckthorn stone & 51.81 & [46] \\
\hline AC with $\mathrm{KOH}$ developed from cashew nut shell & 28.90 & [47] \\
\hline
\end{tabular}




\begin{tabular}{|c|c|c|}
\hline $\mathrm{AC}$ with $\mathrm{H}_{3} \mathrm{PO}_{4}$ developed from peanut shell & 35.46 & {$[48]$} \\
$\mathrm{AC}$ with $\mathrm{Zn} \mathrm{Cl}_{2}$ developed from hazelnut husk & 13.05 & {$[49]$} \\
& & \\
\hline Nanche stone & 8.53 & This study \\
Modified nanche stone with citric acid & 18.78 & This study \\
$\mathrm{AC}$ with $\mathrm{ZnCl}_{2}$ developed from nanche stone & 84.38 & This study \\
\hline
\end{tabular}

With reference to Table 5, the maximum adsorption capacity $\left(\mathrm{q}_{\max }\right)$ of $\mathrm{Pb}^{2+}$ obtained in this research work for the NS, MNS and AC is within the range of those obtained by other researchers with other agricultural residues; even in some cases, with higher adsorption capacity.

\section{Conclusions}

Three different absorbents (NS, MNS and AC) obtained from nanche stone (Byrsonima crassifolia) were effective in the removal of $\mathrm{Pb}^{2+}$ ions. The pHpzc of adsorbents ( $\mathrm{NS}=6.0$; $\mathrm{MNS}=5.6 ; \mathrm{AC}=5.9$ ) was determined in the acid range favoring cation adsorption. Moreover, the main functional groups found in the adsorbents were carboxylic, phenol and lactone groups which contribute to the adsorption of heavy metals. The above is due to two factors: electrostatic interactions between the ions and the adsorbent surface, and specific chemical interactions among the ions and the surface complexes.

The $\mathrm{pH}$ of the solution had a significant effect over the lead ions adsorption because it determined the adsorbent surface charge, ionization grade and metal ion speciation.

Results indicated that it is feasible to improve the adsorption of this metal ion in aqueous solution modifying the nanche stone, initially with citric acid, observing that the adsorption capacity increased 2.2 times. This agricultural waste is the first time that it was used as a precursor to obtain activated carbon, improving the adsorption capacity 10 times demonstrating that it can be an economically viable alternative.

\section{References}

1. Emenike, P.; Omole, D.; Ngene, B.; Tenebe, I. Global J. Environ. Sci. Manage. 2016, 2, 411-442. https://dx.doi.org/10.22034/gjesm.2016.02.04.010

2. Sulyman, M.; Namiesnik, J.; Gierak, A. Pol. J. Environ. Stud. 2017, 26, 479-510. https://dx.doi.org/10.15244/pjoes/66769

3. Tejada, C.; Bonilla, H.; Pino, J.; Villabona, A.; Ortega, R. Rev. Mex. Ing. Quím. 2020, 19, 1413-1423. https://doi.org/10.24275/rmiq/IA1101

4. Zhu, B.; Fan, T.; Zhang, D. J. Haz. Mat. 2008, 153, 300-328. https://doi.org/10.1016/j.jhazmat.2007.08.050

5. Ozdemir, I.; Sahin, M.; Orhan, R.; Erdem, M. Fuel Process. Technol. 2014, 125, 200-206. http://dx.doi.org/10.1016/j.fuproc.2014.04.002

6. Obayomi, K. S.; Bello, J. O.; Nnoruka, J. S.; Adediran A. A.; Olajide, P.O. Cogent Eng. 2019, 6, 117. https://doi.org/10.1080/23311916.2019.1687274

7. Malekian, F.; Ghafourian, H.; Zare, K.; Sharif, A. A.; Zamani, Y. J. Mex. Chem. Soc. 2019, 63, 120129. http://dx.doi.org/10.29356/jmcs.v63i2.666

8. Medina, R.; Salazar, S.; Gómez, J. HortScience 2004, 39, 1070-1073. https://doi.org/10.21273/HORTSCI.39.5.1070 
9. Bayuelo, J.; Lozano, J.; Ochoa, I. Rev. Fitotec. Mex. 2006, 29, 31-36.

10. Caballero, A.; Vela, G.; Pérez, J.; Escobar, R.; Ballinas, J. Etnobiología 2012, 10, 50-55.

11. Guzmán, A.; Cruz, E.; Miranda, C. Rev. Mex. Cien. For. 2013, 4, 82-89. https://doi.org/10.29298/rmcf.v4i20.372

12. Medina, R.; Ibarra, M. E.; González, J. G.; Salazar, S. Rev. Venez. Cienc. Tecnol. Aliment. 2017, 8, 45- 56. https://sites.google.com/site/1rvcta

13. Leyva, R.; Bernal, L. A.; Acosta, I. Sep. Purif. Technol. 2005, 45, 41-49. https://doi.org/10.1016/j.seppur.2005.02.005

14. Monroy, J.; Mendoza, D. I.; Bonilla, A.; Pérez, M. A. Int. J. Environ. Sci. Technol. 2015, 12, $2867-$ 2880. https://doi.org/10.1007/s13762-014-0685-x]

15. Goertzen, S.; Thériault, K.; Oickle, A.; Tarasuk, A.; Andreas H. Carbon 2010, 48, 1252-1261. https://doi.org/10.1016/j.carbon.2009.11.050

16. Prado, M. A.; Arruda, S. M.; Ulson, A. A. J. Clean. Prod. 2014, 65, 342-349. http://dx.doi.org/10.1016/j.jclepro.2013.08.020

17. Chen, R.; Li, L.; Liu, Z.; Lu, M.; Wang, C.; Li, H.; Ma, W.; Wang, S. J. Air Waste Manage. Assoc. 2017, 67, 713-724. http://dx.doi.org/10.1080/10962247.2017.1280560

18. Hock, P. E.; Ahmad, M. A. Acta Chimica Slovaca 2018, 11, 99-106. https://doi.org/10.2478/acs-2018$\underline{0015}$

19. Heidarinejad, Z.; Hadi, M.; Heidari, M.; Javedan, G.; Ali, I.; Sillanpää, M. Environ. Chem. Lett. 2020, 18, 393-415. https://doi.org/10.1007/s10311-019-00955-0

20. Giraldo, L.; Moreno, J. C. Braz. J. Chem. Eng. 2008, 25, 143-151. https://doi.org/10.1590/S0104$\underline{66322008000100015}$

21. Wang, G.; Zhang, S.; Yao, P.; Chen, Y.; Xu, X.; Li, T., Gong, G. Arab. J. Chem. 2018, 11, 99-110. http://dx.doi.org/10.1016/j.arabjc.2015.06.0117

22. Tasar, S.; Özer, A. Pol. J. Environ. Stud. 2020, 29, 293-305. https://doi.org/10.15244/pjoes/103027

23. Singh, J.; Ali, A.; Prakash, V. Int. J. Environ. Sci. Technol. 2014, 11, 1759-1770. https://doi.org/10.1007/s13762-013-0326-9

24. Shi, B.; Zuo, W.; Zhang, J.; Tong, H.; Zhao, J. J. Environ. Qual. 2016, 45, 984-992. https://doi.org/10.2134/jeq2014.12.0533

25. Nuithitikul, K.; Phromrak, R.; Saengngoen, W. Sci. Rep. 2020, 10, 1-14. https://doi.org/10.1038/s41598-020-60161-9

26. Bedia, J.; Peñas, M.; Gómez, A.; Rodríguez, J. J. Carbon Res. 2020, 6, 1-25. https://doi.org/10.3390/c6020021

27. Subha, R.; Namasivayam, C. Indian J. Chem. Technol. 2009, 16, 471-479. http://nopr.niscair.res.in/handle/123456789/6711

28. Acharya, J.; Sahu, J.; Mohanty, C.; Meikap, B. Chem. Eng. J. 2009, 149, 249-262. https://doi.org/10.1016/j.cej.2008.10.029

29. Angin, D. Fuel 2014, 115, 804-811. http://dx.doi.org/10.1016/j.fuel.2013.04.060

30. Obike, A. I.; Igwe, J. C.; Emeruwa C. N.; Uwakwe, K. J. J. Appl. Sci. Environ. Manage. 2018, 22, 182-190. https://doi.org/10.4314/jasem.v22i2.5

31. Siripatana, C.; Khuenpetch, A.; Phromrak, R.; Saengngoen, W.; Nuithitikul, K. J. Eng. Applied Sci. 2017, 12, 1819-1824.

32. Celebi, h.; Gök, O. Int. J. Environ Res. 2017, 11, 83-90. https://doi.org/10.1007/s41742-017-0009-3

33. Saka, C.; Sahin, Ö.; Masuk, M. Int. J. Environ. Sci. Technol. 2012, 9, 379-394. https://doi.org/10.1007/s13762-012-0041-y 
34. Martín, M. A.; Rodríguez, I. 1.; Blázquez, G.; Calero, M. Desal. 2011, 278, 132-140. https://doi.org/10.1016/j.desal.2011.05.016

35. Bulut, Y.; Tez, Z. J. Haz. Mat. 2007, 149, 35-41. https://doi.org/10.1016/j.jhazmat.2007.03.044

36. Wolfová, R.; Pertile, E.; Fecko P. J. Environ. Chem. Ecotoxicol. 2013, 5, 159-167.DOI: 10.5897/JECE09.025

37. Singha, B.; Kumar, S. Environ. Sci. and Pollut. Res. 2012, 19, 2212-2226. https://doi.org/10.1007/s11356-011-0725-8

38. Li, Q.; Zhai, J.; Zhang, W.; Wang, M.; Zhou J. J. Haz. Mat. 2007, 141, 163-167. https://doi.org/10.1016/j.jhazmat.2006.06.109

39. Saleem, J.; Bin, U.; Hijab, M.; Mackey, H.; McKay, G. Biomass Conv. Bioref. 2019, 9, 775-802. https://doi.org/10.1007/s13399-019-00473-7

40. Jahangard, A.; Sohrabi, M.; Beigmohammadi, Z. Iran. J. Toxicol. 2016, 10, 2329.https://doi.org/10.29252/arakmu.10.6.23

41. Bouchelkia, N.; Mouni, L.; Belkhiri, L.; Bouzaza, A.; Bollinger, J.; Madani, K. Separ. Sci.Technol. 2016, 51, 1645-1653. https://doi.org/10.1080/01496395.2016.1178289

42. Mouni, L.; Belkhiri, L., Zouggaghe, F., Tafer M. Desal. Water Treat. 2014, 52, 6412-6419. https://doi.org/10.1080/19443994.2013.812992

43. Alslaibi, T.; Abustan, I.; Ahmad, M.; Abu, A. Desal. Water Treat. 2014, 52, 7887-7897. https://doi.org/10.1080/19443994.2013.833875

44. Chaouch, N.; Ouahrani, M.; Laouini, S. Orient. J. Chem. 2014, 30, 1317-1322. http://dx.doi.org/10.13005/ojc/300349

45. Ahmed, S.; Mohammad, S. Mycopath 2014, 12, 87-93.

46. Mohammadi, S.; Karimi, M.; Afzali, D.; Mansouri, F. Desal. 2010, 262, 86-93. https://doi.org/10.1016/j.desal.2010.05.048

47. Tangjuank, S.; Insuk, N.; Tontrakoon, J.; Udeye, V. Int. J. Chem. Mol. Nucl. Mat. Metall. Eng. 2009, 3, 221-227. https://doi.org/10.5281/zenodo. 1074763

48. Tao, X.; Xiaoqin, L. Chin. J. Chem. Eng. 2008, 16, 401-406. https://doi.org/10.1016/S10049541(08)60096-8

49. Imamoglu, M.; Tekir, O. Desal. 2008, 228, 108-113. https://doi.org/10.1016/j.desal.2007.08.011 